\title{
SMEs Entry Mode Decision Making Process: Rational or Cybernetic?
}

\author{
Rose Quan (Corresponding author) \\ Newcastle Business School, Northumbria University \\ 87 New Bridge, Newcastle upon Tyne, NE1 8ST, England \\ E-mail: rose.quan@northumbria.ac.uk
}

Received: July 21, 2012

doi:10.5430/bmr.v1n3p71
Accepted: July 31, 2012

Online Published: August 30, 2012

\section{Introduction}

The decision making process in foreign market entry mode choices is an important strategic procedure (Argarwal \& Ramaswami, 1992; Almor, 2001; Alon, 2004; Nakos \& Brouthers, 2002). A process-orientated mode, practically, provides rules for decision makers who can apply these rules to their entry mode choices. However, little work has been done at identifying the decision making process in light of firms' strategic entry mode choices (Decker' \& Zhao, 2004), especially in the context of small and medium sized firms (SMEs).

Managers choose different analytical strategies in their decision making. The entry mode literature traditionally assumes that internationalization decisions are rational (Nielsen \& Nielsen, 2011; Brouthers \& Hennart, 2007) According to the rational decision making strategy, the business environment is predictable for decision makers. In this way, managers make the accurate interpretation and evaluate all available information to make their strategic decisions. However, international business (IB) scholars, indeed, ignore the fact that decisions on how to enter foreign markets and how to select the entry modes are characterized by complexity and incomplete information (Hambrick \& Mason, 1984). According to Schwenk (1988), human interactive capacities are limited. Decision makers can only capture limited information (e.g. external environment including political stabilities, market conditions and internal environment mainly related to firms' ownership advantages) rather than all the complexities, especially for SMEs decision makers. Strategic entry decision-making for SME managers is unfamiliar and uncertain. The context of decision making for SME managers is complex and dynamic (Kumar \& Subramaniam, 1997). Following this argument, the cybernetic decision making concept is introduced (Steinbruner, 1974).

According to Steinbruner (1974) and Kumar and Subramaniam, (1997), the cybernetic strategy advocates that decision makers have limited analytic capability. Only limited information can be used when managers make their strategic decisions. Considering constrains SMEs encounters (e.g. lack of resource and experience), it is assume that SME managers tend to use less formal (non-rational) strategy. Nevertheless, the empirical studies of SME managers' strategic entry decision making are limited. Further investigation is needed.

This paper explores what strategic options SME managers adopt in their entry mode choices (rational or cybernetic) and what decision making process these SMEs decision makers employ. By answering these research questions, this paper makes a threefold contribution. First, it integrates entry mode choice literature into the strategic literature in order to illuminate the decision making process that SMEs decision makers adapt. Second, while existing research primarily focuses on influencing factors and their impact on the outcomes of the entry mode choices, this paper contributes to the entry mode literature by investigating another important aspect related to entry decision making process which is something missing in the middle between the influencing factors and final outcomes. It is hoped that the results of this study will provide valuable insights for both IB scholars and managerial practitioners to enrich their understandings of SMEs' entry mode decision making process. Third, it is noted that majority studies of entry mode choices are either based on MNEs or SMEs from developed countries entering developing countries. To enhance our understanding of SMEs' internationalization, studies of SMEs' entry decision making process in different contexts (e.g. Asian SMEs from developing countries enter developed country) is required (Pinho, 2007; Brouthers, Brouthers \& Werner, 1999; 2000).

\section{Theoretical Background}

\subsection{Entry Mode Choice}

Entry mode decision is one of the fundamental strategic decisions when firms expend their business in the foreign 
markets due to its nature of highly uncertain and risky (Nielsen \& Nielsen, 2011). An entry mode is defined as the institutional arrangement by which a firm transfers its products, technologies, human skills, or other resources into a market (Wild, Wild \& Han, 2000). As entry mode choice decisively affects firms' performance at international markets (Brouthers, Brouthers \& Werner, 1999), a number of theories have been developed related to entry mode choices, such as transaction costs analysis (Anderson \& Gatignon, 1986), stage model (Johanson \& Vahlne, 1977), network theory (Cawthorne, 1995; Coviello \& McAuley, 1999; Chetty \& Agendal, 2008) and eclectic paradigm (Dunning, 1988, 1998, 2000).

A number of researchers have attempted to classify different entry modes. According to the leading IB scholars, control is essential for firms' success of foreign investments. Control determines risks and returns (Anderson \& Gatignon, 1986; Roots, 1994). By considering the inter-dependent linkage among control, return and risk, Anderson and Gatignon (1986) divided entry modes into three different levels: high control entry modes (high risks but high returns); medium control entry mode and low control entry mode (low risks but low profits). Focusing on more management perspective, Root (1994) suggested alternative classification of entry modes, including export entry modes (direct and indirect); licensing; joint ventures and wholly owned subsidiaries. Roots' entry mode classification has been accepted as the commonly used entry mode choices in the prior international entry mode literature. These classifications are largely based on considerations of costs; control; benefits and risks. As no one mode is ideal for different types of businesses, different contexts must be taken into account during the entry decision making process (e.g. firms entering different countries).

\subsection{Decision making process: Rational vs. Cybernetic}

Making decisions is one of the most important tasks in managers' daily life. The outcomes of decisions determine a business survival (Lu \& Beamish, 2001). Managers' managerial behavior can be understood through the study of decision processes and decision contexts (Pettigrew, 1988). The decision making process of entry mode choices has drawn a number of researchers' attentions (e.g. Root, 1994; Kumar \& Subramaniam, 1997; Pan \& Tes, 2000; Young et al 1989; Reid, 1981). According to them, different strategic approaches related to entry decision making process can be used at different levels, for instance, the rational decision-making strategy (Mintzberg, Ahlstrand \& Lampel, 1998) and cybernetic decision-making strategy (Lindzey \& Aronson, 1985; Kumar \& Subramaniam, 1997).

Rational decision-making strategy is a deliberate process of conscious thought. Managers adopting this approach make their decision-making as deliberate as possible (Mintzberg, Ahlstrand \& Lampel, 1998). A rational decision-making process requires massive resources commitment, such as collecting and analyzing data, holding/ planning meetings (Johnson \& Whittington, 2006; Porter, 1996). They cybernetic analytical strategy is contrast to rational strategy. The management cybernetics is first introduced by Stafford Beer in the late 1950s. According to Beer (1959), management cybernetics is a field of knowledge which helps decision makers to achieve the right approach to complexity. The cybernetic decision-making strategy draws on Simon's (1955) assumption that human brain hardly obtains a rational solution to problems by considering all elements as it has a limited analytic capability. Extending Simon's (1955) perspective into a manager's strategic decision-making, Steinbruner (1974) propounds a cybernetic model of decision-making which suggests that only limited relevant factors can be taken into account by decision makers. Stenbruner, setting on Simon's bounded rationality, "combined the notions of satisficing and models cognitive process" and argues that "the cybernetic decision makers decomposes the problem and the environment into stable subsystems. Only a small number set of critical variables are monitored and the final decision is made by a sequential process based on some heuristic (Kumar and Subramaniam, 1997: 64)". Many researchers have strongly suggested that strategy selection is a combination of make a correct decision and desire to minimize efforts (Beach \& Mitchell, 1978; Payne, 1982). Drawing from this rational, Kumar and Subramaniam (1997) argue that the choice of cybernetic strategy over the rational strategy can be based on a cost/ benefit analysis.

In the context of international business studies, Kumar and Subramaniam (1997) argue that one of the important Steps in a firm's entry mode choices is to decide what strategic approach can be adopted by decision makers. Taken for granted, international strategic decisions are more complex compared to domestic businesses in a number of ways. Externally, international business often involves foreign currencies, different political and legal systems, and various cultures cross national boundaries. These external factors generate a lot of uncertainties and unpredictabilities. Internally, international organizations face greater challenges to configure and develop their available resources effectively to meet companies' international expansion (Johnson, Scholes \& Whittington, 2006). All these factors make international strategic decision-making a very complex and dynamic process (Aharoni, 1966; Ghauri \& Holstius, 1996; Griffin \& Pustay, 2005; Johnson). Consequently, managers' strategic decisions are dependent on availability and amount of information they can obtain. If the costs of accurate information are too expensive, 
managers may choose cybernetic strategy. Applying this notion into the context of international entry decision making process, Kumar and Subramaniam (1997) assumed that many SME managers intend to use cybernetic strategy because they have limited time and resource to collect immense information. Nevertheless, this assumption is subject to empirical validation. This study fills this gap by exploring SME managers' strategic decisions in relation to entry mode choices.

\subsection{Different Models of Entry Decision Making Process}

Based on rational and cybernetic approaches, different models of entry decision making process are developed. Root (1994) develops an entry decision-making model (see figure 1). This decision model integrates 3 aspects over the entry mode decision planning and process: the availability of company resources, risk and nonprofit objectives. Figure 1 shows that decision makers start with reviewing all different entry modes, then analyzing both external and internal influencing factors on the basis of reliable information. Drawing upon the outcomes of the analysis, the feasibility of entry modes can be decided. The feasible entry modes include, as Root (1998) claims, all possible entry modes to penetrate the target county within the company's resource and commitment capabilities. After feasible entry modes are screened, comparative analyses of profit contributions, risks and nonprofit objectives need to be conducted among these feasible entry modes. Finally, decision makers bring the analytical results together for an overall comparative assessment and rank the feasible entry modes to decide the most appropriate entry mode.

\section{Insert Figure 1 here}

Root's (1994) entry mode decision process shown in figure 1 is based on the assumption of rational decision-making strategy. Decision makers determine their entry mode choices in a deliberate way by screening massive information and spending large amounts of money and efforts. Root (1998) proposes that managers should consider all possible entry modes at the same level in making their entry mode decisions. He asserts that all the factors have the same level of relevance for all entry modes of entry. However, SMEs decision makers do not favorite this entry decision making process practically due to constrains of finance and other resources (e.g. experiences and skills). Drawing on the contingency theory, Kumar and Subramaniam (1997), alternatively, developed a contingency mode of entry decision as presented in figure 2 below.

\section{Insert Figure 2 here}

As shown in figure 2, this contingency entry decision-making process consists of five stages. The first stage involves entry problem recognitions (the entry decision-making context). Second, the entry tasks are evaluated. At this stage, Kumar and Subramaniam (1997) suggest that three questions should be asked: what factors that affect the modes have to be considered, from where information related to these factors can be collected? And how much these information might costs? At the third stage, a decision strategy to solve the entry problem has to be selected. Both rational decision-making strategy and cybernetic decision-making strategy can be adopted at this level. Fourth, information relevant to the selected strategy (either rational or cybernetic) should be collected. Finally, considering all the outcomes of previous four stages, the actual choice of foreign market entry modes will be decided when entering the foreign markets.

Having discussed earlier, managers, using cybernetic strategy, attempt to reduce the complexity in their entry mode choices (Kumar \& Subramaniam, 1997). By doing so, decision makers use a 3 steps process in their entry mode choices: 1) managers use a hierarchical process during the mode of entry decision task; 2) managers consider only a few critical factors at each level; 3) managers consider different factors at different level. Critically, the contingency framework of entry mode decision is too 'general' to provide greater implications for the managers in practice. As the authors themselves suggest "how managers actually make the mode of entry decision should be further investigated (p.69)". Also, it is noticed that this contingency framework is theoretically based and not empirically tested yet.

\subsection{SMEs and Entry Mode Decision}

Prior studies in relation to entry mode choices are grounded in rational choice modes (Nielsen and Nielsen, 2011). This is because large numbers of entry mode studies are developed on the basis of multinational enterprise (MNEs). The nature differences between SMEs and MNEs in terms of size, financial constrains, human resources distinguish their choices of strategic entry mode decisions.

In one of his studies, Buckley (1998) indicates that the role of uncertainties of internationalization looms large in SMEs' decision-making. In addition to bias of information acquisition and time constraints, SME managers normally take short cuts and inadequate evaluations in their international decision making. Further to Buckley's (1998) suggestions, Kumar and Subramaniam (1997) assumed that strategic entry decision-making for SME managers is 
dynamic; the context is complex; and the environment is less-accountable. As a result, SME decision makers tend to use less formal and less elaborate strategy in their entry decision-making process. As Kumar and Subramaniam (1997) assert that a cybernetic decision-making model is more suitable for SME managers in deciding their strategic entry modes since the rational decision-making mode requires massive resources and time commitment. Most SMEs lack of resources and analytical skills to handle comprehensive information (Steinbruner, 1974; Kumar \& Subramaniam, 1997; Musso \& Francioni, 2012).

To sum up, a market entry mode choice is one of the most important issues and critical strategic decision for firms' international expanding as it has strong impact on a firm's future performance (Root, 1994; Decker and Zhao, 2004). Previous research in this area largely focuses on the relationship between influencing factors and entry mode choices. Little attention has been put on the entry mode decision-making process. Indeed, the latter is essential for managers from practice perspective. More empirical studies in this area should be carried out. This paper attempts to fill this research gap in the context of SMEs from the mainland China operating in England.

\section{Research Methods}

Rather than a 'question-answer' survey format, this study employed qualitative research method. This is because the decision making process is best understood through decision makers' personal experience. Such a complexity issue cannot be in-depth explored by a statistic survey (Nadin \& Cassell, 2004; Strauss \& Corbin, 1998). Therefore, the semi-structured interview is the most suitable research method to gain insights of SMEs decision makers' experience (Bryman \& Bell, 2003).

This study sampled Chinese SMEs (CSMEs) from the mainland China operating in the UK. According to Emst and Young European Investment Monitor (2007), UK accounts 40\% of all Chinese investment in Europe and there are 43 Chinese firms operating in this region. The sample consisted of 20 CSMEs either owner mangers or marketing managers. The interview involved three main steps: preparing the interview (e-mailed the participants); conducting the interview (colleting the data for the main study) and post interview (presented the results of the findings). To avoid misunderstanding caused by language obstacles, all interviews were conducted in Chinese during the interviews and translated into English. For each interview conducted, the tape recorded data were listened immediately to check if the interview data was properly recorded. If not, the interviewees are re-contacted and another appointment was made as early as possible. Finally, all the relevant documents for each interview are labeled and filed, including transcripts, informed consent, filed notes, research summary reports.

To ensure that data analysis is 'systematic, sequential, verifiable and continuous (Krueger \& Casey, 2000: 128)', three stages of data analysis are conducted: data reduction, template analysis and data display and drawing conclusions. At data reduction stage, written notes, memos, narrative extracts, as well as some English translations of important quotes are produced. Following the first stage, the template analysis method recommended by King (2004) was employed to identify the key themes. Based on the initial template, after the first round of coding was completed, the transcripts and other research documents are re-read and re-coded. If there were new codes emerged, these codes were arranged into the initial template until the final template was completed. To enhance the high quality of the research outcomes, a post -interview method was used for this study. Four CSMEs managers and one senior governor from the CSMEs provincial Bureau were interviewed after the data analysis were completed.

\section{Findings and Discussions}

The twenty interviewed CSMEs managers were selected from a wide range of industries, including the textile industry (garment and house soft decoration firms); the food industry (soft drink and Chinese food companies); computing industry (computer accessories and software design firms) and Chinese medicine, property renting and consultant firms from the service sector. The number of employees of these firms varies from 5 to 500 . Based on the twenty semi-structured interviews, the findings of this study show that most of the CSME managers adopted a combination of rational strategy and cybernetic strategy at different level by following three consequent stages during their entry decision making process: gathering information, examining relevant influencing factors, deciding the suitable and realistic entry modes.

\subsection{Cybernetic strategy: Gathering Information}

The findings reveal that, as the first step of entry decision process, CSMEs managers started with the information gathering. The assumption of doing this was mainly because of the unfamiliarity of the host country. Manager $\mathrm{N}$ explored that: "Entering England markets was our first foreign investment in Western developed countries, lack of the experience and information really bothered me. Getting relevant information is extremely important." A number of CSME managers stressed the same comments with Manager N. From their accounts, there were so many 
uncertainties and unpredictabilities in the entry mode decision making process. Gathering information helped them to make optimal entry mode decision. These CSME managers used various channels, such as Government agents in the host country, business partners, websites, professional consultant (not many CSME managers can afford), managers' personal contacts in the host countries etc. Some of the CSME managers spent one or two months visiting the UK to search for the first hand market information.

The Manager T from a Chinese food company explained that:

At the beginning, we were JUST about interested in doing business in UK, but we had no clear business idea till we first time visited the UK. During the visit, we found that many Chinese students and scholars living in the North East of England, this information helped us to identify our niche markets. After further investigation and analysis, we started our business here (in the North East of England). In my experience, information must be collected before any decisions have been made. especiallv the accurate. reliable and valid information.

From Manager T's narratives, it was interpreted that the uncertainty of internationalisation was truly a concern of CSME managers in deciding their entry modes when entering England. Most of them confirmed that entering the Western foreign markets was a big decision for them. In this sense, these CSME managers tended to be rational because of the less-accountable environment in the international markets. However, at the same time, these CSME managers made their personal judgements by prioritising different groups of information in their market entry mode choices. The purpose of doing this is simply because these CSMES lacked of not just resources but also the time to collect immense accurate information.

\subsection{Be rational: Data Analysis Stage}

After collecting the information, CSME managers claimed that they moved to data processing and analysis. At this stage, the key influencing factors were carefully analyzed. One CSME manager confirmed that: "I then carefully evaluated the business environment mainly on focus of the marketing structure including customer demands and prices, Government supports, cultural differences between Chinese and British etc." Of note, a number of CSME managers stressed that data processing and analysis stage was very dynamic and contingent. Sometimes, decision makers' interpretations of the collected data varied from one manager to another. So in this sense, results of this stage may lead to different entry mode choices. Most interestingly, some interviewed CSME manager explored that

We had never so systemically spent that much time making a business decision before. Plus, we did not have the experience and (were) unfamiliar with the mode of entry decision comparing with the managers from multinational firms. To choose an optimal entry mode, we had to think carefully in making our decision... a good experience.

Entering foreign markets is different from domestic business activities as it is more complex and difficult, plus the costs, we got be careful ..... I was quite rational in making my entry decisions. I looked the information I had over again and again .... It was kind of experience I never had

From these CSME managers' accounts, two patterns were discovered. First, it was evident that CSME managers tended to be more rational in their entry mode choices compared with their domestic decision-making. In the case of this study, these CSME managers tried to conducted data analysis in a rational manner at some stages during their entry decision-making process. Meanwhile, these CSME managers' personal decision-making attitude and personal characteristics had certain influences on their entry mode choices. For example, different experiences and educational backgrounds may affect their interpretations of collected information, and further influence their entry mode choices. By doing this, the data process and analysis by CSME managers might not be as elaborate as they planned. 


\subsection{Entry Mode Decision: The Best or the Second Best}

From some CSME managers' narratives, the last stage of the decision-making process involved identification of the choice of entry mode. This stage was described by CSME managers as "the most subjective and dynamic stage." The findings of this study show that decision-making at this stage was contingent upon CSME managers' personal characteristic. In addition to CSME managers' knowledge, ability of English language and Western education backgrounds etc., their personal decision-making styles and preferences all their decision making process. For example, according to CSME managers, the time they would like to devote to the analysis and evaluation affects their final entry decision making process, as well as the outcomes of their entry mode choices.

One CSME manager explained how he made his entry mode choice by following this entry mode decision-making process. Most interestingly, he addressed his final entry mode decision by saying that:

What I did was that I had a few options in light of entry mode choices at beginning in my mind such as direct exporting, joint venture and Wholly-owned subsidiary, strategic alliance. To move down the next level, I decided the 'optimal entry mode' by analyzing and evaluating a set of factors and made my choices of 'the best entry mode'. However, the best entry mode sometimes could not be turned into 'the final entry mode' in a real-life situation. For example, I initially wanted to look for a joint venture partner in UK, but we cannot satisfy the potential British partner's needs (financial condition in mainly). Then we had to adopt exporting entry mode as our 'final entry mode'.

Other two managers had similar experiences and comments with the above manager. They both confirmed that they had preferred entry mode after the analysis was conducted. However, to execute it, they had to work hard to overcoming some constraints, such as seeking government support in home countries, negotiating the percentage of shared equity with potential joint venture partners. One of them explained that: "As our efforts made no results, we had to choose the other possible entry mode as our 'final entry mode' instead." Another manager echoed that: "The 'best' one was not always workable, so in this sense, we had to give up the best and choose the second best." According to these CSME managers' experiences, clearly, the decision of the final entry mode in this decision-making process is very dynamic and took long time to finalize it.

\subsection{Discussions}

Regarding the decision-making making process, it seems that both rational strategy (Mintzberg, Ahlstrand and Lampel, 1998) and cybernetic strategy (Lindzey \& Aronson, 1985; Kumar \& Subramaniam, 1997) are adapted by CSME managers. According to existing literature, rational strategy is more suitable for MNEs because rational decision strategy requires various analysis tools and entails very complex procedure. It involves sufficient resources commitment (Johnson, Scholes \& Whittington, 2006; Porter, 1996). SMEs managers, in the contrast, more prefer cybernetic strategy suggested by Kumar and Subramaniam's (1997). Building upon the data analysis and the findings presented earlier, this research illuminates that CSME managers adopted a combination of the cybernetic strategy and rational strategy approach in their entry mode choices. It extended the existing literature that suggests that SME managers normally take short cuts and inadequate evaluations in their international decision making (Buckley, 1998).

The findings of this study show that, on the one hand, CSME managers in general are unable (or would not be willing to invest) to afford financial budgets due to the expensive costs in terms of collecting high quality of information. Consequently, it is not reliable for them to make comprehensive analysis rationally. Instead, only a certain critical set of factors based on the limited information were considered by these CSME managers. On the other hand, entering foreign market is different from domestic business expanding. The decision making in international scenario is more dynamic and complex (Aharoni, 1966; Ghauri \& Holstius, 1996; Griffin \& Pustay, 2005; Johnson, Scholes \& Whittington, 2006). Rational strategy is requires at certain levels. This result did not follow the lead of Buckley (1998) who stated that SMEs normally take short cuts and inadequate evaluations in their international decision making. Together, it is concluded that CSME managers adopted the combination of rational and cybernetic strategy when they decide entry mode choices. This result corroborated with Beach and Mitchell (1978) and Payne (1982) who suggested that the strategy selection should be the results of compromise between to make a correct decision and desire to minimize efforts. It is also consistent with the cybernetic strategy originally 
from Simon's (1955) and Steinbruner (1974), which has not been empirically tested in the prior studies.

Furthermore, building upon process-oriented models in line with firms' foreign market entry mode choices, this research more explicitly paints a picture of how SME managers made their entry mode choices. According to Root (1998), MNEs often start with examining all entry modes at the same level and then decide the feasible entry modes based on the outcomes of the internal and external analysis. Nevertheless, the findings of this study did not completely support Root's decision making model since CSME managers did not examine all entry modes at the first stage. The different entry modes were only considered at the last stage. In addition, comparing with Kumar and Subramaniam's (1997) five step contingency model, the first three stages (e.g. problem recognition, evaluating time and resources and selection of decision strategy) did not adapt by CSME managers in their entry mode decision-making process in this study. Evidently, CSME managers started with external information gathering related to markets demands and cultural differences in England. Indeed, these CSMEs managers did not clearly know what strategy they were going to adapt initially until they collected the relevant data they needed. The combination of rational and cybernetic strategies was only employed at the data analysis stage. The process-oriented model developed in this study is similar with Kumar and Subramaniam's (1997) contingency model in the step four 'data collection' and the step five 'decision choices of entry mode', but it clearly brought more details than contingency mode and provided more practical insights for CSME managers in line with their decision- making process of entry mode choices.

\section{Conclusions and Implications}

Foreign market entry mode choice is a critical decision when firms expand their business internationally (Ekeledo \& Sivakumar, 1998, 2004; Dunning, 1993). Many existing entry mode studies attempt to identify the influencing factors and their impact on the outcomes of entry mode choices. Very few studies, however, investigate how entry mode decisions are actually made. This paper has made great efforts to explore how SMEs decision makers decide their entry mode choices, especially with the focus on their strategic decision making process. Building upon the experiences of the CSME managers' entry decision making experience, a process-oriented model was developed by integrating different resources in this study (see figure 3).

\section{Insert Figure 3 here}

As shown in figure 3, this process-oriented model combined different components together in three stages: Information gathering, data processing and making the final entry decision. In deciding what kind information need to be collected, a cybernetic strategy was adopted in the first instance since time, energy and financial constraints prevented SME managers from taking deliberate and rational decision making strategy. When analyzing influencing factors, SME managers attempt more rational compared to the information gathering stage. Finally, a contingent approach is adopted in making the final choices of entry mode. Regarding the entry mode choices, SME managers first made their selection between possible entry modes and rejected entry modes, then followed by choosing the best entry mode they desired. If the 'best' entry mode is not feasible due to some reasons (e.g. financial constraints; political barriers), the 'second best' is selected as their final entry mode choice. Empirically, this study partially confirmed Kumar and Subramaniam's (1997) theoretical assumption in which SME managers follow the hierarchical process, but provides new insights which confirms that SME managers combine rational strategy and cybernetic strategy at different levels.

This study attempts to extend knowledge of SME managers' entry mode choices with focus on CSMEs managers' decision making process in the context of operating in England. Of note, this is the first time that this topic has been empirically studied on the basis of CSMEs operating in a Western developed country. The findings of this study have several implications. First, this research suggests that SME managers attempt to be rational in making their entry mode choices, especially comparing with domestic business decisions. This implies that SME managers should distinguish differences between international and domestic strategic decision making and make good use of firms' resources. The second implication applies to practice on SME managers' entry mode selections. The findings show that a SME, at least in CSMEs investigated in this study, may not adapt the 'best entry mode' after information gathering and data analysis. Instead, the 'second best' in many cases is realistic. Finally, SME managers must aware of the hierarchy structure during the decision making process. In doing this, decision makers can reduce the problems.

It is recognized that this study has a number of limitations as every study does. First, the outcomes of this study are not generalizable due to the nature of the qualitative study. As this study is specific context oriented, practitioners may only apply the findings by considering certain circumstances. The future research may use survey method to overcome this limitation. In addition, the sampled firms are from both manufacturing and service sectors. This could 
potentially lead to the second limitation since manufacturers are different from service firms in many aspects. According to IB leading researchers (Erramilli, 1990, 1991; Erramilli \& Rao (1993), research results generated from manufacturing sector may not be applicable to service companies. IB researchers need investigate SMEs' entry mode decision making process by separating the manufacturing and service sectors in the future. Such studies will enhance the understanding of SME managers' decision making behavior.

\section{References}

Agarwal, S. \& Ramaswami, S. R. (1992). Choice of Foreign Market Entry Mode: Impact of Ownership, Location and Internalisation Factors. Journal of International Business Studies, 23(1), 1-27. http://dx.doi.org/10.1057/palgrave.jibs.8490257

Aharoni, Y. (1966). The Foreign Investment Decision Process. In P. Buckley, \& P. N. Ghauri, (Eds.) The Internationalization of the Firm: A reader ( $2^{\text {nd }}$ ed.). London: International Thomson Business Press.

Almor, T. (2001). Towards a Contingency View of Market Entry Strategies: Contextual and Strategic Factors. Journal of Euro-marketing, 10(1), 5-25. http://dx.doi.org/10.1300/J037v10n01_02

Alon, I. (2004). International Market Selection for a Small Enterprise: A Case Study in International Entrepreneurship. SAM Advanced Management Journal, Winter, 25-32.

Anderson, E. \& Gatignon, H. (1986). Modes of Foreign Entry: A Transaction Cost Analysis and Proposition. Journal of international Business Studies, 17(3), 1-26. http://dx.doi.org/10.1057/palgrave.jibs.8490432

Beach, L. \& Mitchell, T. R. (1978). A Contingency Model for the Selection of Decision Strategies. Academy of Management Review, 3, 439-449.

Beer, S. (1959). Cybernetics and Management. London: English University Press.

Brouthers, K. D., Brouthers, L. E. \& Werner, S. (1999). Dunning's Eclectic Theory and the Smaller Firm: The Impact of Ownership and Locational Advantages on the Choice of Entry-modes in the Computer Software Industry. Journal of International Business Research, 5(4), 377-396. http://dx.doi.org/10.1016/0969-5931(96)00019-4

Brouthers, L. E., Brouthers, K. D. \& Werner, S. (2000). Perceived Environmental Uncertainty, Entry Mode Choice and Satisfaction with EC-MNC Performance. British Journal of Management, 11(3), 183-195. http://dx.doi.org/10.1111/1467-8551.00160

Bryman, A. (2004). Social Research Methods ( $2^{\text {nd }}$ ed.). Oxford: Oxford University Press.

Buckley, P. J. (1998). Models of Multinational Enterprise. Journal of International Business Studies, 29(1), 21-44. http://dx.doi.org/10.1057/palgrave.jibs.8490023

Coviello, N. E. \& McAauley, A. (1999). Internationalization and the Smaller Firm: A Review of Contemporary Empirical Research. Management International Review, 39(3), 223-234.

Decker, R. \& Zhao, X. (2004). SME Choice of Foreign Market Entry Mode: A Normative Approach. International Journal of Business Economics, 3(3), 181-200.

Dunning, J. H. (1988). The Eclectic Paradigm of International Production: A Restatement and Some Possible Extensions. Journal of International Business Studies, 19(1), 1-31. http://dx.doi.org/10.1057/palgrave.jibs.8490372

Dunning, J. H. (1998). Location and the Multinational Enterprise: A Neglected Factor. Journal of International Business Studies, 29(1), 45-66. http://dx.doi.org/10.1057/palgrave.jibs.8490024

Dunning, J. H. (2000). The eclectic Paradigm as an Envelope for Economic and Business Activity. International Business Review, 9(1), 10-29.

Ekeledo, I. \& Divakumar, K. (1998). Foreign market entry mode choice of service firms: A contingency perspective. Journal of the Academy of Marketing Science, 26(4), 274-292. http://dx.doi.org/10.1177/0092070398264002

Ekeledo, I. \& Divakumar, K. (2003). International market entry mode strategies of manufacturing firms and service firms: A resource-based perspective.. International Marketing Review, 21(1), 68-101. http://dx.doi.org/10.1108/02651330410522943

Erramilli, M. K. (1991). The Experience Factor in Foreign Market Entry Behavior of Service Firms. Journal of International Business Studies, 22(3), 479-501. http://dx.doi.org/10.1057/palgrave.jibs.8490312

Erramilli, M. K. (1990). Entry Mode Choice in Service Industriey. International Marketing Review, 7(5/6), 50-62.

Erramilli, M. K. \& Rao, C. P. (1993). Service Firms' International Entry-Mode Choice: A Modified Transaction-Cost 
Analysis Approach. Journal of Marketing, 57(July), 19-38. http://dx.doi.org/10.2307/1251852

Ghauri, P. \& Holstius, K. (1996). The Role of Matching in the Foreign Market Entry Process in the Baltic State. European Journal of Marketing, 30(2), 75-88. http://dx.doi.org/10.1108/03090569610106671

Griffin, R. W. \& Pustay, M. W. (2005). International Business.(4th ed.). Harlow: Prentice Hall.

Hambrick, D. C. \& Mason, P. A. (1984). Upper Echelone: The organization as a refelction of its top managers. Academy of Management Review, 9, 193-206.

Johanson, J. \& Vahlne, J. E. (1977). The international process of the firm-a Mode of knowledge development and increasing foreign market commitments. Journal of International Business Studies, 7(4), 23-32. http://dx.doi.org/10.1057/palgrave.jibs.8490676

Johnson, G., Scholes, K. \& Whittington, R. (2006). Exploring Corporate Strategy ( $7^{\text {th }}$ ed.). London: Prentice Hall.

King, N. (2004). Using Templates in the Thematic Analysis of Text. In C. Cassell, \& G. Symon, (eds) Essential Guide to Qualitative Methods in organizational Research. London: Sage.

Krueger, R. \& Casey, M. (2000). Focus Groups: A Practical Guide for Applied Research (3 ${ }^{\text {rd }}$, ed.). Thousand Oaks: Sage.

Kumar, V. \& Subramaniam, V. (1997). A Contingency Framework for the Mode Entry Decision. Journal of World Business, 32(1), 53-72. http://dx.doi.org/10.1016/S1090-9516(97)90025-0

Lindzey, G. (1985). The Handbook of Social Psychology. New York: Random House.

Lu, J. W. \& Beamish, P. (2001). The Internationalization and Performance of SMEs. Strategic Management Journal. 22, 565-586. http://dx.doi.org/10.1002/smj. 184

Mintzberg, H.; Ahlstrand, B. \& Lampel, J. (1998). Strategy Safari . New York: Free Press.

Nadin, S. \& Cassell, C. (2004). Using data marices. In C. Cassell, \& G. Symon, (Eds). Essential guide to qualitative methods in organizational research. London: Sage.

Nagel, A. (1981). Strategy Formulation for the Smaller Firms: A practical Approach. Long Range Planning, 14(4), 115-120. http://dx.doi.org/10.1016/0024-6301(81)90129-1

Nakos, G., Brouthers, K. D. \& Moussetis, R. (2002). Entry Mode Choice of SMEs in Central and Eastern Europe', Entrepreneurship: Theory \& Practice. 27 (1), 47-63. http://dx.doi.org/10.1111/1540-8520.271003

Nielsen, B. B. \& Nielsen, S. (2011). The role of top management team international orientation in international strategic decision-making: The choice of foreign entry mode. Journal of World Business, 46, 185-193. http://dx.doi.org/10.1016/j.jwb.2010.05.003

Pan, Y. \& Tse, D. K. (2000). The Hierarchical Model of Market Entry Modes. Journal of International Business Studies, 31(4), 535-554. http://dx.doi.org/10.1057/palgrave.jibs.8490921

Payne, J. W. (1978). Contingent Decision Behavior. Psychological Bulletin, 92(2), 382-402. http://dx.doi.org/10.1037/0033-2909.92.2.382

Reid, S. (1981). The Decision-Maker and Export Entry and Expansion. Journal of International Business 1Studies, Fall, 101-112.

Root, F. R. (1994). Entry Strategies for International Markets. San Francisco,:Jossey-Bass Publishers.

Schwenk, C. (1988). The cognitive perspective on strategic decision making. Journal of Management Studies, 25(1), 41-55. http://dx.doi.org/10.1111/j.1467-6486.1988.tb00021.x

Simon, H. A. (1955). A behavioural model of rational choice. Quanterly Journal of Economic.

Steinbruner, J. D. (1974) The Cybernetic Theory of Decision. Princeton: Princeton University Press.

Strauss, A. \& Corbin, J. C. (1998). Basic of qualitative research: Techniques and procedures for developing grounded theory $\left(2^{\text {nd }}\right.$ ed.). Thousand Oaks: Sage.

Young, S., Hood, N. \& Hamill, J. (1988) Foreign Multinationals and the British Economy. London: Croom Helm. 


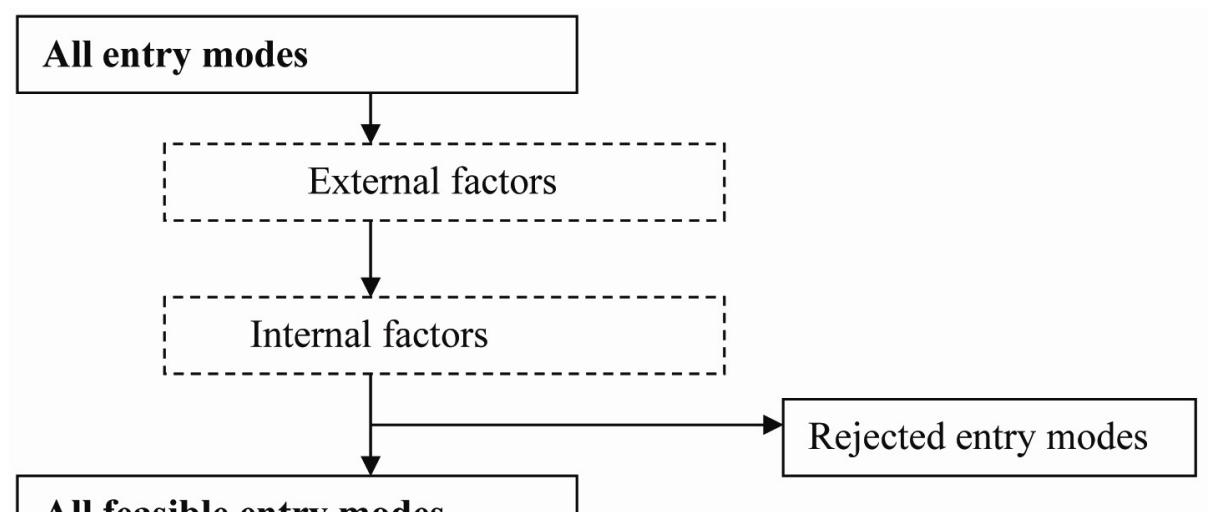

\section{All feasible entry modes}

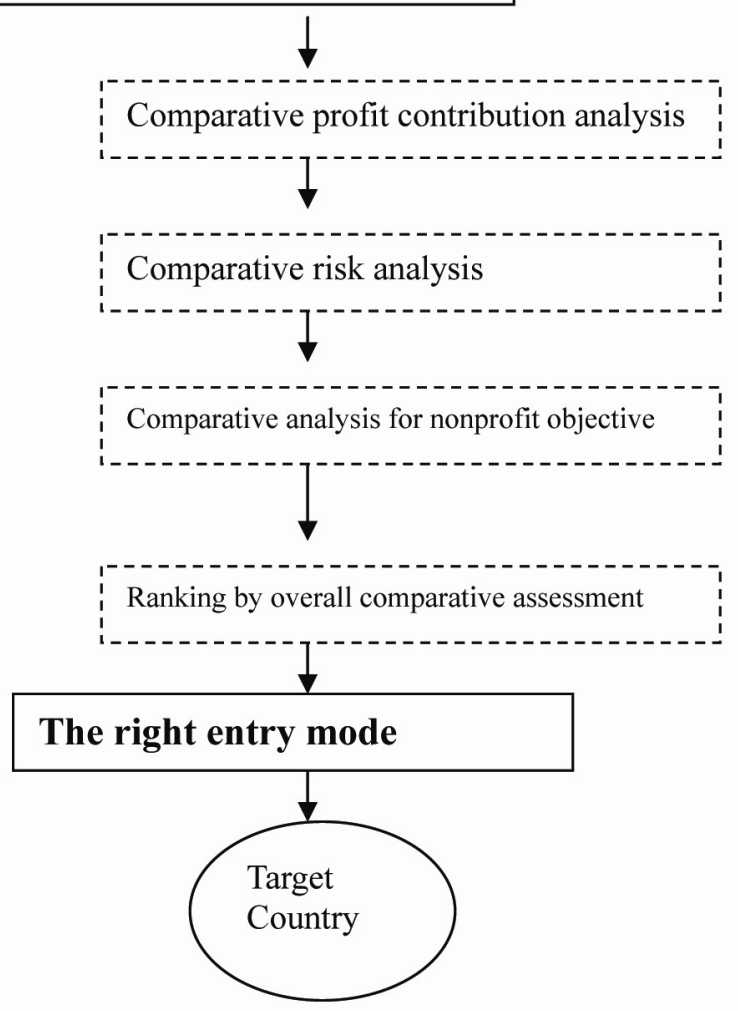

Figure 1. Foreign market entry decision process

Source: Root (1994) Entry Strategies for International Markets.

San Francisco: Jossey-Bass Publishers.

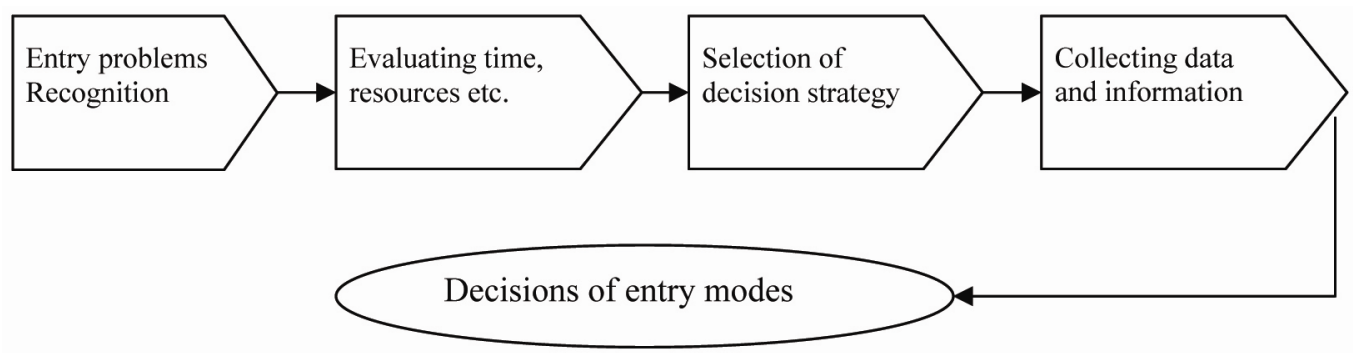

Figure 2. A contingency model of entry decision

Source: Adapted from Kumar and Subramaniam (1997) 'A contingency framework for the mode of entry decision'. Journal of World Business, 32(1), pp53-72. 


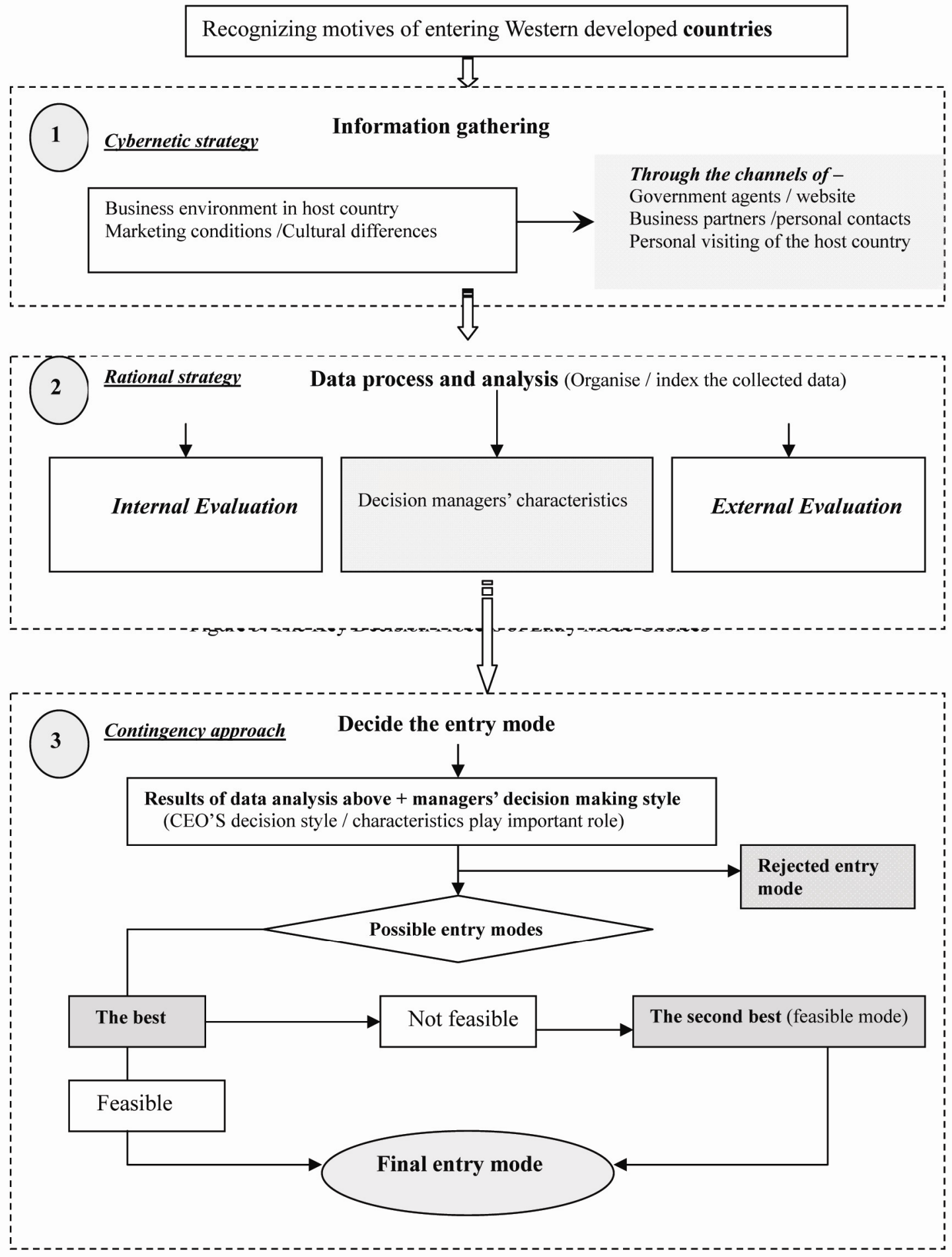

Figure 3. The Key Decision Process of Entry Mode Choices 